\title{
Prevalence of different cytomorphological types of transmissible venereal tumours and the association with prognosis in dogs treated with vincristine sulphate - Retrospective study
}

\section{Prevalência dos diferentes tipos morfológicos de tumor venéreo transmissível e a associação com o prognóstico dos cães tratados com sulfato de vincristina - Estudo retrospectivo}

\author{
Cristiane Sella Paranzini ${ }^{1}$; Marcos Cézar Sant'anna²; \\ Giovana Wingeter di Santis ${ }^{3}$; Maria Isabel Mello Martins ${ }^{4 *}$
}

\begin{abstract}
Canine transmissible venereal tumours (CTVT) are the most commonly diagnosed tumours in veterinary hospitals. CTVT is morphologically classified as a round cell tumour, although the exact origin of the cells is unknown. Immunohistochemical studies have suggested histiocytic and mesenchymal origin. CTVT can be classified as lymphocyte-like, plasmocyte-like, and mixed according to their cytomorphological features. The treatment of choice for CTVT is chemotherapy with vincristine sulphate applied weekly; this produces a good prognosis. However, an increase in the number of chemotherapy applications and adjuvant therapies has become common. The aim of this study was to determine the association of cytomorphological types of CTVT with resistance and partial resistance to vincristine sulphate and the possible need for a large number of chemotherapy sessions. A retrospective study of a 24-month period evaluated 46 diagnosed and treated cases of CTVT. It was concluded that there is a higher prevalence of plasmacyte-like, followed by mixed and lymphocyte-like CTVT. The cytomorphological type did not differ in relation to the response to the treatments with vincristine sulphate and the number of chemotherapy sessions necessary for CTVT regression has increased by factors not yet elucidated.
\end{abstract}

Key words: CTVT, cytology, prognosis

\section{Resumo}

O tumor venéreo transmissível canino (TVT) é a neoplasia mais comumente diagnosticada nos hospitais veterinários, morfologicamente é classificado como células tumorais redondas, embora a origem exata dessas células seja desconhecida, estudos imunohistoquímicos sugerem origem histocítica e mesenquimal. O TVT pode ser classificado de acordo com suas características citomorfológicas como linfocítico, plasmocítico e misto. Geralmente são benignos, entretanto podem apresentar metástase. O tratamento de escolha do TVT é quimioterapia com sulfato de vincristina aplicada uma vez por semana, com um bom prognóstico. Contudo, nos últimos anos tem se observado a necessidade de aumento no número de aplicações da quimioterapia e terapias adjuvantes. O objetivo nesse estudo foi associar os tipos morfológicos de TVT com a resposta a quimioterapia com sulfato de vincristina, em um estudo

\footnotetext{
Mestranda do Programa de Pós-Graduação em Ciência Animal, área de Sanidade Animal, Universidade Estadual de Londrina,UEL, Londrina, PR. Brasil. E-mail: kitvet@gmail.com

2 Doutorando do Programa de Pós-Graduação em Ciência Animal, área de Sanidade Animal, UEL, Londrina, PR. E-mail: santannamarcos@bol.com.br

3 Prof $^{a}$ Adjunto do Dept ${ }^{\circ}$ de Medicina Veterinária Preventiva, DMVP/UEL, Londrina, PR, Brasil. E-mail: gio@hotmail.com

${ }^{4}$ Prof $^{\text {a }}$ Associada do Dept ${ }^{\circ}$ de Clínicas Veterinárias, DCV/UEL, Londrina, PR, Brasil. E-mail: imartins@uel.br

Author for correspondence
} 
retrospectivo realizado no período de 24 meses com 46 casos. Pode-se concluir que há uma maior prevalência dos tipos de TVT plasmocítico, seguido do misto e depois do linfocítico, e que os tipos citomorfológicos não diferem em relação à resposta ao tratamento com sulfato de vincristina. O número de sessões de quimioterapia necessárias para regressão do TVT teve um aumento por fatores ainda não elucidados.

Palavras-chave: Citologia, prognóstico, TVT

Canine transmissible venereal tumour (CTVT), known for 70 years as Sticker's tumours (ROGERS, 1997; AMARAL et al., 2007) is a contagious tumour that commonly occurs in the dog. Although this tumor is reported worldwide, it is more predominant in tropical and subtropical urban areas (HANTRAKUL et al., 2014) in freeroaming and pour management dog's control area (HANTRAKUL et al., 2014; STRAKOVA; MURCHISON, 2014).

CTVT is morphologically classified as a round cell tumour, although the exact origin of the cells is unknown. Immunohistochemical studies suggest histiocytic and mesenchymal origin (AMARAL et al., 2007). CTVTs are usually benign but there is a risk of relapse and metastasis (MARTINS et al., 2005; AMARAL et al., 2007). CTVTs are predominantly diagnosed in the vaginal and penile mucosa and occasionally in extra genital regions, such as the nasal and/or oral mucosa, skin, and ovary (AMARAL et al., 2007; COSTA, 2009). CTVT is transmitted during copulation via the implantation of tumour cells by direct contact with genital mucosa or cutaneous lesions at the time of breeding or in nasal and oral cavities due to the habit of sniffing and licking (PÉREZ et al., 1994).

Macroscopically, the masses have a cauliflower appearance but can also manifest as plaques and necrotic tissue (grey) and can be friable. The animal may have serosanguineous secretion, vulvar and preputial deformities due to tissue destruction, intense smell, ulceration and itching at the affected region, altered behaviour, aggression, and in severe cases, urinary retention (MARTINS et al., 2005, TINUCCI-COSTA, 2009).

The definitive diagnosis can be made by cytology of the mass. Usually, alterations are found only after two or three weeks of implantation (GREATTI et al., 2004). Cytologically, CTVT cells are round or oval, 14 to $30 \mu \mathrm{m}$ in diameter, with pale blue cytoplasm that is distinctly vacuolated, with a relatively high nuclear: cytoplasmic ratio. The cells also contain dense chromatin, visible nucleoli and numerous mitotic structures, including anisocytosis and anisokariosys (ERUNAL-MARAL et al., 2000).

The treatment of choice for CTVT is chemotherapy, weekly, with vincristine sulphate that has been shown to be effective and can be used alone or in combination with other drugs (OGILVIE \& MOORE, 1995; MARTINS et al., 2005). The involution of the lesions is gradual and the complete remission occurs after two to eight applications in approximately $90 \%$ of treated cases (MARTINS et al., 2005). Chemotherapy with doxorubicin every 21 days could be an alternative for the treatment of resistant CTVT (COSTA, 2009).

Previous studies have observed different types of cells in CTVT. Rogers (1997) suggested two lineages of CTVT, and one of these was related to metastases. Ferreira (2000) reported a case of intraocular CTVT for which the diagnosis was only possible after immunohistochemical evaluation because the histopathological pattern was unusual and did not allow for an initial diagnosis. Recently, morphologically studies have subclassified CTVTs as follows: lymphocyte-like, formed predominantly by round tumour with a high proportion of nucleus:cytoplasm (similar to lymphocytes); plasmocyte-like, consisting of cells with oval nuclei and a lower proportion of nucleus:cytoplasm (similar to plasma cells); or mixed forms, in which both of the two patterns are present (AMARAL et al., 2007; GASPAR et al., 2009). 
Recent studies have associated plasmocyte-like CTVT with higher aggressiveness and malignant potential, and it was found to be associated with the development ofmetastases, extragenital presentation (AMARAL et al., 2007), increased resistance to the antitumour action of propolis (BASSANISILVA, 2007), and higher immunoreactivity for P-glycoprotein, which is associated with resistance to multiple chemotherapeutic agents (GASPAR et al., 2009).

The aim of this study was to determine the prevalence of different cytomorphological types of CTVT diagnosed and treated at the Veterinary teaching Hospital, and associate these variations with tumour regression using vincristine sulphate.

A retrospective study was done with cases of CTVT diagnosed and treated at a Veterinary teaching Hospital during 24 months (January 2012 to December 2013).

The cytomorphological types of CTVT were diagnosed and classified according to Amaral et al. (2007) and Gaspar et al. (2009). CTVTs were classified as lymphocyte-like or plasmocyte-like when at least $60 \%$ of the neoplastic cells similar to lymphocytes or plasma cells were observed, respectively, and as mixed pattern when the two morphological types were present in similar proportions. All of the dogs included in the study were initially treated weekly with $0.5 \mathrm{mg} / \mathrm{m}^{2}$ vincristine sulphate.

During the analysis, the cases were clinically classified as effective (when the tumour suffered complete regression with vincristine sulphate chemotherapy after 6 sessions); cauterization adjuvant (when tumour regressed considerably after vincristine sulphate chemotherapy but cauterisation was necessary after the $6^{\text {th }}$ session); and unresponsive (when it was necessary to change the chemotherapeutic agent because there were no regression after the $3^{\text {rd }}$ session). In the latter case, chemotherapy with doxorubicin $\left(30 \mathrm{mg} / \mathrm{m}^{2}\right)$ was administered every 21 days. Patients received medical discharge after being diagnosed cytological negative for CTVT.

To determine possible differences between association and independent variables with biological plausibility and dependent variables, Fisher's exact test and Chi-square were calculated; $\mathrm{P}<0.05$ was considered as significant. All statistical analyses were done by using the statistical program Epi Info 3.5.4 (2012).

During this study, 46 dogs diagnosed and treated with CTVT were classified according to their cytomorphological type. Plasmacyte-like CTVTs were the most prevalent (45.6\%), followed by mixed pattern (37.8\%) and lymphocyte-like (19.7\%). CTVT was diagnosed more frequently in females (63.6\%; 28/46). Table 1 illustrates the prevalence of cytomorphological types and the frequency by gender.

Comparing the response to the treatment with vincristine, $2.3 \%(1 / 46)$ was not responsive, $34.1 \%(15 / 46)$ needed cauterization adjuvant to the treatment and $63.6 \%(28 / 46)$ had a good response to the treatment (Table 2).

Table 1. Distribution of the prevalence and frequency of sex according to the classification of cytomorphological CTVTs diagnosed at the Institutional Veterinary Hospital from 2012 to 2013.

\begin{tabular}{lcccc}
\hline & Plasma cell-like & Lymphocyte-like & Mixed & Total \\
\hline Prevalence \% (n) & $45.6 \%(21)$ & $19.7 \%(9)$ & $37.8 \%(16)$ & $(46)$ \\
Sex & & & & \\
Male & $47.6 \%(10)$ & $11.1 \%(1)$ & $31.3 \%(5)$ & 16 \\
Female & $52.4 \%(11)$ & $88.9 \%(8)$ & $68.8 \%(11)$ & 30 \\
\hline
\end{tabular}


Table 2. Difference between cytomorphological patterns of transmissible venereal tumours (lymphocyte-like, plasma cell-like and mixed forms) in tumour response to vincristine sulphate.

\begin{tabular}{|c|c|c|c|}
\hline & Effective ** & Cauterization Adjuvant *** & Not responsive $* * * *$ \\
\hline $\begin{array}{l}\text { Plasmocyte-like } \\
\text { N / total }\end{array}$ & $15 / 21^{\mathrm{a}}$ & $6 / 21^{a}$ & $0 / 21^{a}$ \\
\hline $\begin{array}{l}\text { Lymphocyte-like } \\
\text { N / total }\end{array}$ & $7 / 9^{a}$ & $1 / 9^{a}$ & $1 / 9^{a}$ \\
\hline $\begin{array}{l}\text { Mixed } \\
\text { N / total }\end{array}$ & $9 / 16^{a}$ & $7 / 16^{a}$ & $0 / 16^{a}$ \\
\hline
\end{tabular}

*Fisher's exact test and Chi-square test with a significance level of 5\% $(\mathrm{P}<0.05)$.

$* *$ Effective $=$ tumour showed complete regression with only chemotherapy with vincristine $<7$ applications.

$* * *$ Cauterization $=$ tumour cauterisation was necessary because the tumour did not respond to treatment with vincristine only but had regressed considerably with 7 aplicações.

$* * * *$ No response $=$ tumour didin't show any reduction with 3 applications of vincristine sulphate and it was necessary to change the chemotherapy adding doxorubicin.

a Same letters means that there was no statistical difference.

In this study, the average number of vincristine sulphate injections was $6.27 \pm 1.82$, with a minimum of one and a maximum of eleven chemotherapy sessions. The treatments were applied weekly until complete remission of CTVT and/or cauterization.

There was no statistical difference $(\mathrm{P}=0.13)$ between plasmacyte-like CTVT and other cytomorphological types related to the number of applications with vincristine sulphate.

The prevalence of cytomorphological CTVT types found in this study were similar to Amaral et al. (2007), where they reported $52.5 \%$ of plasmacyte-like, $29.1 \%$ of mixed pattern and $18.4 \%$ of lymphocyte-like tumour cells from a total of 132 cases of CTVT studied. Also, similar to Martins et al. (2010) - that described $45.5 \%$ plasmacyte-like and mixed patterns, and 9\% lymphocyte-like. Both studies showed a higher percentage of plasmacytelike and mixed pattern than lymphocyte like cells.

The prevalence of cytomorphological CTVT types found in this study are similar to that described by Martins et al. (2010) where a higher incidence of plasmacyte-like and mixed patterns (45.5\% each) and lower to lymphocyte-like (9\%) were observed.

Morbidity was more pronounced in females (65.2\%); similar results were dscribed by Scarpelli et al. (2010) when they studied prognostic variables for CTVT in dogs at the Centre for Zoonoses Taubaté SP. The population of street dogs used in that study with a cytological diagnosis of CTVT is similar to the results described during this investigation; this is probably because mostly dogs treated were semidomiciled animals. The high incidence in females may be related to reproductive behaviour, because duirng oestrus females can mate with several males (SOBRAL et al., 1998).

In cases of TVT, that did not respond to vincristine sulphate chemotherapy, other chemotherapeutic agents with cytotoxic action could be used (TINUCCI-COSTA, 2009); these include cyclophosphamide with or without prednisone, vinblastine, methotrexate or a combination of the last three. More recently, doxorubicin administered at a dose of $30 \mathrm{mg} / \mathrm{m}^{2}$ intravenously every 21 days is an alternative for cases that are resistant to vincristine sulphate (COSTA, 2009). In this study, only one case was resistant to vincristine sulphate treatment, and doxorubicin was used successfully.

Calvet et al. (1982) treated 41 patients with vincristine sulphate and achieved complete remission in 39 animals, with an average of three applications of chemotherapy. Silva (2007) achieved an 80\% 
cure rate with an average of five applications, and only $11 \%$ required six or seven applications. In this study, 26/46 (56.5\%) of the cases achieved healing with six or less applications and 20/46 (43.5\%) required more than six applications, which indicates an increasing trend of tumour resistance to vincristine sulphate. At our veterinary hospital, the treatment protocol for CTVT consists of tumour cauterization after the 7 th chemotherapy session when there is incomplete regression with vincristine sulphate. Therefore, the application average of 6.3 +1.8 would be greater if cauterization was not established. In a previous study, our study group also observed similar average of chemotherapy session with vincristine sulphate $(6.7 \pm 2.8)$ (MARTINS et al., 2010). The number of sessions were variable to Hantrakul et al. (2014), ranging from the minimal of three and maximum of eight.

No evidences were found that the cytomorpholgical types are involved in tumour resistance to vincristine sulphate since no significant differences were observed when the distribution of cases between the groups (total resistance, partial resistance and sensitive to vincristine sulphate) was compared (Table 2). Amaral et al. (2007) have compared cytomorphological CTVT types and have shown that plasmacyte-like CTVT was associated with a greater number of metastases, tumour recurrence, extragenital presentation and increased expression of P-glycoprotein and concluded that plasmacyte-like CTVT had more malignant characteristics compared with lymphocytelike CTVT. Gaspar et al. (2009) suggested the P-glycoprotein expression and plamocyte-like tumour possibly being involved in this resistance.

The conditions in which the treatment was instituted and the assessed analysis showed it could not be associated to resistance. Other variables should be evaluated for better understanding of this problem as: immune status, concomitant diseases and estrous cycle during treatment.

It can be concluded that no associations were found between cytomorphological type and tumour resistance to vincristine sulphate and the number of chemotherapy sessions necessary for CTVT regression has increased by factors not yet elucidated.

\section{References}

AMARAL, A.; BASSANI-SILVA, S.; FERREIRA, I.; FONSECA, L.; ANDRADE, F.; GASPAR, L.; ROCHA, N. Cytomorphological characterization of transmissible canine venereal. Revista Portuguesa de Ciências Veterinárias, Lisboa, v. 103, n. 563-564, p. 253-269, 2007.

BASSANI-SILVA, S.; SFORCIN, J.; AMARAL, A.; GASPAR, L.; ROCHA, N. Própolis effect in vitro on canine transmissible venereal tumor. Revista Portuguesa de Ciências Veterinárias, Lisboa, v. 22, n. 563-564, p. 261-265, 2007.

CALVET, C. A.; LEIFER C. E.; McEWEN, E. G. Vincristine for the treatment of transmissible venereal tumor in the dog. Journal of the American Veterinary Medical Association, Schaumburg, v. 181, n. 2, p. 163164, 1982.

COSTA, M. Tumor venéreo transmissível canino. In: DALECK, C. R. Oncologia em cães e gatos. São Paulo: Roca, 2009. p. 539-536.

EPI Info ${ }^{\mathrm{TM}}$. Version 3.5.4. StatCalc algorithms and formulas. Atlanta: Centers for Disease Control and Prevention, 2012. Available at: <http://www.cdc.gov/ epiinfo>. Accessed at: 7 may 2014.

ERUNAL-MARAL, N.; FINDIK, M.; ASLAN, S. Use of exfoliative cytology for diagnosis of transmissible venereal tumor and controlling the recovery period in the bitch. Deutsche Tierarztliche Wochenschrift, Hannover, v. 107, n. 5 , p. 175-180, 2000.

FERREIRA, A. Brain and ocular metástases from a transmissible venereal tumor in a dog. Journal of Small Animal Practice, Malden, v. 41, n. 4, p. 165-168, 2000.

GASPAR, L. F. J.; AMARAL, A. S. do; BASSANISILVA, S.; ROCHA, N. S. Immunoreactivity of the p-glycoprotein in the different cytomorphologic types of canine transmissible venereal tumor. Veterinaria em Foco, Canoas, v. 6, n. 2, p. 140-146, 2009.

GREATTI, W.; AMARAL, A.; BASSANI-SILVA, S.; GASPAR, L.; BARBISAN, L.; ROCHA, N. Índices proliferativos do tumor venéreo canino transmissível pelas técnicas do CEC e KI-67 na citologia aspirativa com agulha fina. Archives of Veterinary Science, Curitiba, v. 9, n. 1, p. 53-59, 2004. 
HANTRAKUL, S.; KLANGKAEW, N.; PÉREZ, J.; BAUTISTA, M. J.; CARRASCO, L.; KUNAKORNSAWAT, S.; TANSATIT, T.; GOMEZ-VILLAMANDOS, J. C.; MOZOS, E. Primary POAPOLATHEP, A.; KUMAGAI, S.; POAPOLATHEP, extragenital occurrence of transmissible venereal tumors: S. Clinical pharmacokinetics and effects of vincristine three case reports. Canine Practice, Santa Bárbara, v. 19, sulfate in dogs with transmissible venereal tumor (TVT). The Journal of Veterinary Medical Science, Tokyo, v. 76, n. 12, p. 1549-1553, 2014.

MARTINS, M. I. M.; MARTINS, W. C.; SANT'ANNA, M. C.; DI SANTIS, G. W. Cytomorphological patterns of canine transmissible venereal tumour subtropical área and sensitivity to chemotherapy with vincristine sulphate. In: EUROPEAN VETERINARY SOCIETY FOR SMALL ANIMAL REPRODUCTION (EVSSAR) CONGRESS, 7., 2010, Louvain-La-Neuve. Proceedings... LouvainLa-Neuve, 2010. p. 125.

MARTINS, M. I. M.; SOUZA, F.; GOBELlO, C. The canine transmissible venereal tumor: etiology, pathology, diagnosis and treatment. In: CONCANNON, P.; ENGLAND, G.; VERSTEGEN, J.; LINDE-FORSBERG, C. Recent advances in small animal reproduction. Ithaca NY: International Veterinary Service 2005.

OGILVIE, G. K.; MOORE, A. S. Managing the veterinary cancer patient. Veterinary Learning System. Trenton, NJ. 1995. 542 p. n. 1, p. 7-10, 1994.

ROGERS, K. Transmissible venereal tumor. Compendium on Continuing Education for the Practising Veterinarian, Princeton, v. 19, n. 9, p. 1036-1045, 1997.

SCARPELLI, K.; VALADÃO, M.; METZE, K. Predictive factors for the regression of canine transmissible venereal tumor during vincristina therapy. The Veterinary Journal, Inglaterra, v. 183, n. 3, p. 362-363, 2010.

SILVA, M. Avaliação epidemiológica, diagnóstica e terapêutica do tumor venéreo transmissível (TVT) na população canina atendida no hospital veterinário da UFERSA. Acta Veterinária Brasílica, Mossoró, v. 1, n. 1, p. 28-32, 2007.

SOBRAL, R.; TINUCCI-COSTA, M.; CAMACHO, A. Ocorrência do tumor venéreo transmissível em cães na região de Jaboticabal. Ars Veterinária, Jaboticabal, v. 14, n. 1, p. 1-10, 1998.

STRAKOVA, A.; MURCHISON, E. P. The changing global distribution and prevalence of canine transmissible venereal tumour. BMC Veterinary Research, Londres, v. 10, n. 168, p. 1-10, 2014.

TINUCCI-COSTA, M. Tumor venéreo transmissível canino. In: DALECK, C.R.; DE NARDI, A. B.; RODASKI, S. Oncologia em cães e gatos. São Paulo: Roca, 2009. p. 539-556. 